\title{
Emotional intelligence and self-efficacy career decision making among high school students
}

\author{
Muhamad Syamiezy Sidek ${ }^{1}$, Abu Yazid Abu Bakar ${ }^{2}$ \\ ${ }^{12}$ Universiti Kebangsaan Malaysia, Malaysia
}

\begin{tabular}{l} 
Article Info \\
\hline Article history: \\
Received Dec $12^{\text {th }}, 2019$ \\
Revised Jan $20^{\text {th }}, 2020$ \\
Accepted Feb $10^{\text {th }}, 2020$
\end{tabular}

\section{Keyword:}

Career decision

Emotional intelligence

High school students

Self-efficacy

\begin{abstract}
Lack of self-confidence in decision making is one of the dominant problems that often engage students in making career choices. This study aimed to answer three research questions, namely, 1) is there a difference in emotional intelligence based on gender, 2) is there a difference in self-efficacy in career decision making among form four based on gender factors, 3) is there a relationship between emotional intelligence and self-efficacy making career decisions among form four students. The study sample was 80 respondents in a secondary school. This study is a survey study and uses the Emotional Intelligence test as well as the Career Decision Self-Efficacy test (CDSE-SF). The data were analyzed using SPSS version 24 . The results showed that there was no difference between emotional intelligence and self-efficacy based on gender. Besides, the study also found no relationship between emotional intelligence and self-efficacy in career decision making. This study supports counselors and various working groups with adolescents to assist students in their career path from school to school.
\end{abstract}

(C) 2020 The Authors. Published by IICET.

This is an open access article under the CC BY-NC-SA license (https://creativecommons.org/licenses/by-nc-sa/4.0

\section{Corresponding Author:}

Abu Yazid Abu Bakar,

Universiti Kebangsaan Malaysia

Email: yazid3338@ukm.edu.my

\section{Introduction}

Career is a very important part of human life. It is through the work of man that he has the means to support his life, to support those under his care and to serve the people. As such, the importance of a career is hard to deny especially in today's world (Noah, 2012). However, career choices in today's world are increasingly more complex because of the wide range of human capabilities and desires. The rapid growth of the country has given rise to the field of specialization in education and employment. Individual decisions in choosing a job can be either right or wrong. It depends on the maturity of the person and the guidance they receive before making any final decision. However, regardless of the choice or decision made by the individual, an effective selection system adopted by an organization should be able to identify the right candidates and reject or distribute the candidates that are not appropriate to the other organization (Noah, 2012).

Self-efficacy is a person's belief and ability in managing and also performing the actions required to cope with various situations and problems (Bandura, 1997). The basic principle in the theory of self-efficacy is that the achievement and motivation of an individual is determined by self-belief. Individuals will also be more likely to engage in activities that are closely related to the self-efficacy they have than other activities. Through self-efficacy, this will provide a basis for human motivation, personal achievement and also personal wellbeing. 
According to Betz and Hackett (1981), the self-efficacy of career decision-making is the expectation of a person to act as needed to make or reach a decision. It refers to the belief in an ability to organize and execute the cognitive, behavioral and social skills necessary for success in a task (Schunk, 1991).

Emotional intelligence or intelligence is a concept that attempts to explain how a person controls selfcontrol and is skilled in interpersonal interactions with a variety of individuals in different backgrounds or complex situations (Hassan, 2013). Bar-On (1997) defines emotional intelligence as an emotional ability that includes the ability to control oneself, have the ability to face a problem, be able to control, motivate, manage the mood, and be able to empathize and build relationships with others.

Therefore, emotional intelligence is an important part of measuring self-awareness, emotional control skills, self-motivation, empathy and social relationships that a person needs to have. Hence, an individual's self-efficacy in making career decisions is one of the important aspects of understanding and finding satisfaction in the career to be pursued.

Today, adolescents especially students in Malaysia need to be constantly able and persistent in facing every challenge so that their commitment to learning at school does not fade after graduation. The challenge of students is not only in the field of academic excellence but also in preparing for career success that should begin at the beginning of the school year and not at the end of the school year. This issue is often addressed and some students are excellent academics but still lack confidence and do not feel comfortable and emotional when dealing with work.

School students especially, often face problems in career choice. The problems are an inability to make career decisions, lack of personal and career information, lack of certainty about the career they want to choose, inability to solve problems, and lack of interest in planning. These issues are also closely linked to lack of career maturity (Rohany, 2003). Mature problems in making career decisions will affect students when faced with academic institutions, as well as in the field of employment.

Most students in Malaysia make their career choices without having to go through systematic preliminary planning. According to Arthur \& Hashim (1994) analysis of career choice has shown that there are many types of styles practiced by students ie there are also students who do not have extensive knowledge and do not want to know new types of careers. They find it easier to choose a career focused on their environment. This has led them to choose a career based on what their family members have done or what other careers they have seen through the open and there is no extensive knowledge of career choices. Mohd Yatim (1991) has stated that career and career choices are one of the major issues often posed by an individual in his or her life. This has shown that to decide a career election must be made with strategic planning.

Based on the issues and issues discussed in the career, it is clear that emotional intelligence and self-efficacy play an important role in helping students make career decisions. Therefore, it can be concluded that it is in line with the title of the researcher, which is to identify emotional intelligence and self-efficacy in making career decisions among form four. Adolescents with low levels of emotional intelligence will have problems from the level of emotional stability and self-control to make decisions. Having chosen career will also cause the student to have problems as he or she does not fit into the field they are taking and hence the problem of one's emotional intelligence. Whereas students with low levels of self-efficacy will be overshadowed by fear and lack of confidence in making the career decisions they need to make.

This study aimed to answer three research questions, namely, 1) is there a difference in emotional intelligence based on gender, 2) is there a difference in self-efficacy in career decision making among form four based on gender factors. To conduct this study, the researcher has assigned the importance of this study to several parties. This study will provide insight into the emotional intelligence and self-efficacy of making career decisions for form four students. Therefore, this study will provide some insight into the level of emotional intelligence and self-efficacy of career decision making among form four students.

It is hoped that this study will be able to help form four students adjust to the field of study or field of interest to make informed career decisions and to know what level of knowledge they have in their careers. In addition, this study is expected to benefit the school especially the guidance and counseling teachers, teachers, administrators to better understand and understand the needs and needs of form four students and to work together to help shape the true self of the student be able to give birth to students who will benefit from religious, family, race and national.

Besides, knowledge of emotional intelligence and self-efficacy will help students and teachers to develop strategies and ways to create a conducive environment so that their emotional intelligence and self-efficacy can be built more positively. Therefore, it can be concluded that this study will be of interest to students, guidance and counseling teachers, teachers, administrators, and parents. Therefore, it is hoped that this study will be 
able to make it clear to all parties that the emotional intelligence and self-efficacy among these students is an important factor in students' abilities, interests, competencies, and skills.

\section{Method}

This study is a descriptive field study that is analyzed with descriptive and inferential analysis. This study involved form four students in a boarding school. The student list has been provided by the administrator to the researcher to conduct the survey. The list of students' names is given at random. The administrators also provided a space at the school auditorium to gather all students related to the study. A total of 40 boys and 40 girls were gathered and then placed in two rows by gender. The researcher then explained the purpose of the gathering, which was for a survey and asked the respondents to answer the questionnaire. The time given to the respondent was 40 minutes.

This study used a set of questionnaires divided into three parts. Part A deals with student demographic information while Part B aims to find out the level of emotional intelligence by using Emotional Intelligence inventory while Part $\mathrm{C}$ aims to find out the self-efficacy of career decision making using the Career Decision Making Self-Efficacy- Short-Form (CDSE-SF) inventory.

Emotional Intelligence questionnaire developed by Goleman (1995) and modified by Malek, Noah, Marzuki, Joharry, Lihanna, Shafeq, Jamaludin, Sapon, Yusop, Taib, Munirah, Norlena, Ruhaibah, and Tajulripin (2009) on the level of emotional intelligence consisting of 31 items and a four-point Likert scale. The questionnaire measures the level of emotional intelligence which encompasses five constructs namely 1) self-motivation, 2) social relationships, 3) emotion control 4) self-awareness 5) empathy. Emotional intelligence questionnaire consisted of 30 positive items and one negative item. The Self-efficacy Questionnaire or acronym in the English CDSE-SF, (Betz, Klein, Taylor, 1996) was used to measure selfefficacy expectations. CDSE-SF has five constructs consisting of 25 items that measure five choices: 1) selfevaluation, 2) gathering job information, 3) goal selection, 4) planning and 5) problem-solving.

\section{Results and Discussions}

\section{Descriptive Results}

This descriptive statistical analysis describes data for the subject's background in terms of frequency and percentage. The descriptive analysis results are as follows:

a. Number of Respondents by Gender

Table 1 Gender Frequency Distribution

\begin{tabular}{ccc}
\hline Gender & Sample & Percentage \\
\hline Boys & 40 & 50.0 \\
Girls & 40 & 50.0 \\
\hline Total & 80 & 100.0 \\
\hline
\end{tabular}

Table 1 shows the number of respondents based on gender among four high school students. The findings clearly show that the respondents of the study were 80 respondents, 40 male, and 40 female students. Respondents were selected equally to facilitate the researcher to perform data analysis.

b. Respondents' Emotional Intelligence Levels

Table 2 Respondents' Emotional Intelligence Levels

\begin{tabular}{ccc}
\hline Emotional Intelligence Levels & Frequencies & Percentage \\
\hline Low & 13 & 16.3 \\
Medium & 67 & 83.3 \\
\hline Total & 80 & 100.0 \\
\hline
\end{tabular}

According to Table 2 shown above, the emotional intelligence level of the respondent has a low and medium level. Of the 80 respondents surveyed 67 students of which $83.3 \%$ had moderate levels of emotional intelligence while 13 students of $16.3 \%$ had low levels of emotional intelligence. 
The results of the descriptive analysis conducted to measure the level of emotional intelligence of the respondents showed that the level of emotional intelligence of the respondents was at a moderate level. Of the 80 respondents surveyed, 67 were at a low level while the other 13 were at the low level. As stated earlier, based on the results of the study, the researchers were of the view that the emotional intelligence level of the respondents was at a moderate level. This may be due to several factors. Among them were the respondents who had just completed their mid-year exams and the results of the exams were coming out when the questionnaire was distributed. Therefore, it is likely that this caused the respondents to be at a moderate level. Besides, respondents' emotional intelligence level was at a moderate level due to their rural environment. Rural students are different from urban students. It is possible that their environment is less motivated and motivated to motivate themselves.

Parents also greatly influence children's emotions. Most parents in rural areas do not put their expectations too high for their children to achieve. As such, it can be a factor in students' lack of motivation as parents are less stressed on the level of achievement within the student. Also, family background factors can also influence the students' emotional intelligence at a moderate level. Most of the students at the school have an issue in family background. Because some of these factors can make the respondents studied at that time have a moderate level of emotional intelligence.

Based on the theory of emotional intelligence, according to Goleman (2009), it has been shown that several factors influence one's emotional intelligence - family or non-family factors. Family factors are parental education given to children that will affect their emotional intelligence when they are older. If children are raised in a family with positive emotions, they will have a positive effect on adulthood and vice versa, as well as non-family factors like the environment and education that a person gains in adulthood (Goleman, 2009).

c. Respondents' Level of Self-Efficacy in Making Career Decisions

Table 3 Respondents' Level of Self-Effectiveness in Making Career Decisions

\begin{tabular}{ccc}
\hline Level of Self-Efficacy in Making Career Decisions & Frequencies & Percentage \\
\hline Low & 1 & 1.3 \\
Medium & 23 & 28.8 \\
High & 56 & 70.0 \\
\hline Total & 80 & 100 \\
\hline
\end{tabular}

Based on Table 3 above, the self-efficacy level of decision making, of the 80 respondents of 56 students, $70.0 \%$ had high levels of self-efficacy in career decision making. There were 23 students, of whom $28.8 \%$ had moderate levels of self-efficacy and one student or $1.3 \%$ had low levels of self-efficacy in making career decisions among study respondents.

While the level of self-efficacy made the respondents' career decisions at the high and medium level. Of the 80 respondents surveyed, 56 of them were on a high level while 23 were on the moderate level while only 1 of the respondents were on the low level. As previously stated, based on the results of the study, the researchers argue that the self-efficacy of career decisions is high. This may be due to several factors. Among these is the possibility that the counselor in the research school conducting this study provides career information good for students. The questionnaire was distributed after the respondents had been in the form of several months in the fourth grade, possibly by the respondent who had made the class selection and was given a clear explanation by the counselor causing the students to feel confident about making a career choice.

Besides, the findings of this study also show that students in schools conducted by researchers have shown that the level of confidence of students in making career decisions is high. This indicates that students do not rely on emotional intelligence alone to make career decisions. Therefore, the level of self-efficacy in making career decisions in the school is high.

Based on social cognitive career theory, according to Bandura (1986) self-efficacy, outcome expectations and goals are related. This refers to the self-efficacy of the individual's ability to succeed in completing the assigned tasks. It is the individual who develops the self-efficacy of personal performance, learning by example, social interaction and how the individual feels in a situation. Whereas outcome expectations are beliefs related to the consequences of certain behaviors. Generally, the expectation of this outcome is shaped by beliefs related to specific behaviors such as experience. While the goal is to decide to start something in the future, based on these findings', students have their own goals for achieving something in the future. 


\section{Inferential Results}

The inference analysis used was t-test and ANOVA. The t-test was used to test differences in emotional intelligence as well as self-efficacy in career decision-making among form four students by gender factors, while correlation analysis was used to test the relationship between emotional intelligence and self-efficacy in career decision-making among study's respondents.

The independent t-test analysis showed that there was no difference in the level of emotional intelligence based on gender, $\mathrm{t}(78)=0.561, \mathrm{p}>0.05$. However, the mean value of the boys' emotional intelligence level was 1.84 higher than that of the female students at 1.82 . This indicates that there is no emotional intelligence based on gender. Thus, Ho argues that there is no significant difference between emotional intelligence based on gender, which has been rejected.

In this study, it can be seen from the results of the inference analysis that the mean values of emotional intelligence and self-efficacy of male students' career interests are higher than that of female students. This finding is supported by Zhou Jiang (2016) who also found that male students have higher levels of emotional intelligence and self-efficacy than female students. However, studies of Zhou Jiang (2014), Weiyan, Meng, and Qingqing (2015) found that no gender-based differences were also identified.

The analysis showed that t-test results for self-efficacy in career decision making showed no difference in self-efficacy in career-based decision making, $\mathrm{t}(78)=0.403, \mathrm{p}>0.05$. The mean of self-efficacy decision making for male students was 2.72 higher than that of female students at 2.65 . It also shows that there is no difference between the self-efficacy of making career-based decisions. Thus, it indicates that there is no difference between the self-efficacy of career-based decision-making that fails to be rejected.

Besides, the findings of this study also found no relationship between emotional intelligence and selfefficacy of career interests. The findings of this study, however, contradict the findings of a previous study by Brown (2003) who found that all levels of emotional intelligence were positively related to self-efficacy of career interests. Farid and Suharnan (2013) also found that emotional intelligence is related to self-efficacy. Also, these results indicate that emotionally well-developed emotional intelligence improves one's self-efficacy.

The results also show the analysis results for the correlation test. The results of the study found that there was no relationship ( $\mathrm{r}=-.018, \mathrm{p}=.872$ ) between emotional intelligence and self-efficacy in career decisions. This is because, the correlation test results show a significant value of .872 and this value is above the significance level of 0.05 . Thus, it reveals that there is no significant relationship between emotional intelligence and selfefficacy in making career decisions.

There are similarities in the results of studies with studies conducted by Zhou Jiang (2016), Zhou Jiang (2014), and (Fabio \& Kenny, 2011) who found that there was no significant relationship between emotional intelligence and self-efficacy in career decision making among students. The results of this study do not support the findings of Islami (2013), which show that there is a significant relationship between emotional intelligence and self-efficacy in career decision making.

After conducting a study on this topic, the researcher began to realize some of the things that all parties should take seriously for the sake of common interest. Although this study is only disclosure and learning to the researcher on how to conduct the study, the results of the research that the researcher has obtained are very valuable for joint evaluation.

Overall, the results of this study identify the relationship between emotional intelligence and self-efficacy in career decision making among Form Four students. The sample of studies conducted on Form Four students has its basis. With the research being conducted, the researcher gets impulsive decisions about emotional intelligence and self-efficacy make career decisions among form four students. They have a moderate level of emotional intelligence, yet they can make high career decisions. This opens the eyes of the researcher that, even if a student's level of emotional intelligence is at a moderate level, they can't develop the confidence to make career decisions on their own. Besides, this study found that low emotional intelligence was not related to a student's career decision. This can be seen when the findings show that there is no relationship between emotional intelligence and self-efficacy in career decisions.

This study also has implications for the Ministry of Education Malaysia and schools. School counselors can use student self-efficacy (CDMSE) questionnaires to see how well a student is confident in making career decisions for students in grades three, four and five. While students may no longer understand their careers, at least they know what a career is and they have the confidence to make their career decisions. Also, counselors are better prepared to diversify programs in schools to enhance and disseminate emotional and career-related information to students. Counselors will also be more willing to administer the rest of their inventories so that they can know their potential clearly without any confusion. Finally, it is possible allowing counselors to show 
students the right path with the guidance and results of information provided to them. In school, too, it is the responsibility of the counselor to assess the extent to which the student develops into a positive person and is good at managing himself well in all aspects.

For parents, they need to know the developmental and emotional levels of their children. This is because in addition to school students will spend more time at home. Being with this family is the starting point for a teenager's development. Parents should constantly monitor their children and evaluate how well their emotions are developing and can make good career decisions. They should also encourage children to make career decisions. Parents are not encouraged to determine their children's careers if they are not interested in the option. This is because it can affect a student's level of emotional intelligence if he or she is forced to venture into areas of interest. Therefore, all parties have implications for the research conducted by the researcher. Therefore, the researcher needs to make this study fully available to the benefit of all parties.

In order to carry out this study, there are several limitations of this study which is that the study will focus only on form four students at a school in Pahang. Therefore, the findings of the study will be limited to the sample of the study that will be in the study area.

The population and sample of the study that will be taken to be the respondents of this study will only be among the students at one of the secondary schools in Pahang district, which will consist of male and female students. The sample of this study will also be limited to those students who did not sit for the important examination during the year.

Next, the research information is obtained through sample responses to questionnaire instruments. Therefore, this information may depend largely on the respondents' understanding of the questionnaire as well as the honesty of the sample answering those questions. This may affect the degree of reliability of the study. However, some steps will also be taken to ensure the reliability of this study. First, the description of the instrument and its' procedures have been given orally and in writing to the student sample. Second, respondents will be asked to respond to the instrument at the same time and are not allowed to bring it back.

As a result of the findings and discussion of findings, several things need to be planned and evaluated to ensure that school students will benefit and be aware of their future interests. Therefore, some suggestions will be put forward to ensure this happens. Some of these suggestions are:

a. Every student's emotional intelligence needs to be identified by the teachers, especially to the school counselor. This is because most school students are not able to identify their emotional intelligence levels. Emotional intelligence is an important aspect for students because from this emotional intelligence we can see the level of emotional intelligence of a person. Although this study found that emotional intelligence has no bearing on students' decision making. However, emotional intelligence is an important aspect and is always monitored because counselors can see the level of motivation that a student has.

b. Students also need to be as open as possible about career matters. The counselor is responsible for helping students find information about their careers. Therefore, counselors need to conduct career guidance and counseling among school students to ensure that they have more detailed information as well as in-depth and up-to-date career information. If students do not have this career information, they will have trouble choosing their next job. School counselors can design and organize or create a career resource center with pamphlets, posters and career-related info in the space. Besides, the use of computers to find job-relevant info is also important today. In keeping with the current generation of teenagers they prefer to be exposed to electronic materials, it is not wrong for school counselors to open a special website to discuss their careers and other student-related content on the site. This is why students are more likely to like it because they can read and find information whenever they need it.

c. Students should also be given the space and opportunity to choose the flow that suits them rather than based solely on academic achievement. The school should give the student a chance to choose the flow that the student is interested in and feel they can accept the flow he/she is taking. This is because if the student is not allowed to choose the appropriate field, their emotions will be affected and the student's academic performance will be affected.

Parents should also be exposed to career-related information. This is because parents are significant individuals and have a great impact on student life. Many things including the emotional side of the child and the choice of career are sometimes influenced and determined by the parents. This can sometimes be a problem for students because it is necessary to meet the demands of the parents rather than what they are interested in and feel they can afford it. However, some students do not know how to express this dissatisfaction that can affect their emotions. It can also create conflict and create a rebellious spirit within the 
students. Therefore, in this case, counselors also need to play a role in providing parents with exposure to career info to help students avoid emotional problems when choosing a career.

\section{Conclusions}

In conclusion, this study aims to see whether the aspect of emotional intelligence influences the selfefficacy of respondents' career decision making ability. The results of the study show that there is no significant relationship between emotional intelligence and self-efficacy in career decision making among respondents. The findings of the study, implications, findings of the findings and recommendations have been elaborated and presented as a guide to relevant parties such as schools, ministries, and future researchers. All research questions were also answered as a result of this study. Therefore, the various suggestions and expectations left behind in the continuation of this study to ensure not only student development but also in the work environment are also important aspects of the students' lives.

\section{References}

Bandura, A. (1997). Self-efficacy: The exercise of control. In Self-efficacy: The exercise of control. New York, US: W H Freeman/Times Books/ Henry Holt \& Co.

Bar-On, R. (1997). The Emotional quotient inventory (EQ-i) Technical manual. Toronto: Multi Health Systems.

Basir, M. (2004). Faktor-Faktor yang Mempengaruhi Perkembangan Kerjaya dalam Kalangan Professor dan Professor Madya di Universiti Malaysia Sarawak. Unpublished Thesis. Fakulti Sains Kognitif dan Kemanusiaan. Universiti Malaysia Sarawak.

Betz, N.E., \& Hackett, G. (1986). Applications of self-efficacy theory to understanding career choice behavior. Journal of Social and Clinical Psychology, 4(3), 279-289. https://doi.org/10.1521/jscp.1986.4.3.279

Betz, N.E., Klein, K.L., \& Taylor, K.M. (1996). Evaluation of a short form of the Career Decision-Making Self-Efficacy Scale. Journal of Career Assessment, 4(1), 47-57. https://doi.org/10.1177/106907279600400103

De Weerdt, M., \& Rossi, G. (2012). The Bar-On Emotional Quotient Inventory (EQ-i): Evaluation of Psychometric Aspects in the Dutch Speaking Part of Belgium. https://doi.org/10.5772/38875

Hassan. S.N.S. (2013). Kecerdasan Emosi Anak, Ibu Bapa dan Pendidik yang Cemerlang. Penerbit Universiti Teknikal Malaysia Melaka.

Islami, Ridho. (2013). Hubungan Antara Kecerdasan Emosional Dengan Efikasi Diri Guru Agama Islam (Ustadz) Dalam Pembelajaran Di Pesantren Darusy Syahadah Boyolali. Unpublished Thesis. Fakultas Psikologi dan Fakultas Agama Islam Universitas Muhammadiyah Surakarta

Ismail, M.S., Abdullah, A.H., Zain, A.D.M., Shuhari, M.H., Ariffin, M.R. (2018). Kematangan Kerjaya Pelajar: Implikasinya Terhadap Kaunseling Kerjaya Jurnal Islam dan Masyarakat Kontemporari ISSN 2289 6325. Bil. 18, No. 1, 2018 (Sep)

Jiang, Z. (2014). Emotional intelligence and career decision-making self-efficacy: National and gender differences. Journal of Employment Counseling, 51(3), 112-124. https://doi.org/10.1002/j.21611920.2014.00046.x

Jiang, Z. (2016). Emotional Intelligence and Career Decision-Making Self-Efficacy: Mediating Roles of Goal Commitment and Professional Commitment. Journal of Employment Counseling, 53(1), 30-47. https://doi.org/10.1002/joec.12026

Malek, A.K., Noah, S.M., Marzuki, W., Joharry, N.Z., Lihanna., Shafeq, S.M., Jamaludin., Sapon., Yusop, M., Taib. M., Munirah., Norlena., Ruhaibah., Tajulripin. (2009). Kecerdasan Emosi Dalam Kalangan Remaja Malaysia. Jurnal Bitara, 2, 1-13.

Noah, S. M. (2012) Perkembangan Kerjaya Teori Dan Praktis. Serdang, Selangor: UPM Press.

Schunk, D.H. (1991). Self-efficacy and academic motivation. Educational Psychologist, 26: 207-231.

Weiyan, Z., Meng, L., Qingqing, L. 2015 The Relationship Between Emotional Intelligence and Career Decision- making Self- efficacy of College Students; School of mental health, Ji'ning Medical University, Shandong Province Humanities and Social Science Research Base-Behavior and Health Research Base; CJFDTOTAL

Yapono, F. (2013). Konsep-Diri, Kecerdasan Emosi Dan Efikasi-Diri. Persona:Jurnal Psikologi Indonesia, 2. https://doi.org/10.30996/persona.v2i3.136 